\title{
Adsorption of carmoisine A from wastewater using waste materials-Bottom ash and deoiled soya
}

\author{
Vinod K. Gupta ${ }^{a, b, *}$, Alok Mittal ${ }^{c}$, Arti Malviya ${ }^{c}$, Jyoti Mittal ${ }^{c}$ \\ a Department of Chemistry, Indian Institute of Technology Roorkee, Roorkee 247667, India \\ ${ }^{\mathrm{b}}$ King Fahd University of Petroleum and Minerals, Dhahran, Saudi Arbia \\ ${ }^{\mathrm{c}}$ Department of Chemistry, Maulana Azad National Institute of Technology, Bhopal 462 051, India
}

\section{A R T I C L E I N F O}

\section{Article history:}

Received 3 February 2009

Accepted 6 March 2009

Available online 5 April 2009

\section{Keywords:}

Carmoisine A

Bottom ash

Deoiled soya

Isotherms

Kinetics

\begin{abstract}
A B S T R A C T
The present study deals with the application of bottom ash, a power plant waste, and deoiled soya, an agricultural waste, for the adsorptive removal of carmoisine A dye from its aqueous solutions. This paper incorporates a comparative study of the adsorption characteristics of the dye on these effective adsorbents along with effects of time, temperature, concentration, and $\mathrm{pH}$. Analytical techniques have been employed to find pore properties and characteristics of adsorbent materials. Batch adsorption studies, kinetic studies, and column operations have also been performed to understand the dye extraction ability of the adsorbents. The adsorption behavior of the dye has been studied using Freundlich, Langmuir, Tempkin, and Dubinin-Radushkevich adsorption isotherm models. The monolayer adsorption capacity determined from the Langmuir adsorption equation has been found as $1.78 \times 10^{-5}$ and $5.62 \times 10^{-5} \mathrm{~mol} \mathrm{~g}^{-1}$ at $323 \mathrm{~K}$ for bottom ash and deoiled soya, respectively. Kinetic measurements suggest the involvement of pseudo-second-order kinetics in both adsorptions and each case is controlled by a particle diffusion process. Column experiments demonstrated that both adsorbents could be practically utilized in elimination of hazardous dye from effluent and dye material can be recovered by eluting $\mathrm{NaOH}$ through the exhausted columns.
\end{abstract}

(c) 2009 Elsevier Inc. All rights reserved.

\section{Introduction}

In recent years removal of dyes from wastewaters has received great attention due to the detrimental affects of effluents discharged from sectors such as textile, leather, rubber, plastic, and food industries in the environment. The dye containing colored wastewater damages the aesthetic nature of water and enhances the chances of toxic impact on the aquatic flora and fauna. These water-soluble dyes offer considerable resistance for their biodegradation due to their complex structures and high thermal and photo-stability. Hence, removal of dyes from wastewaters using economic means has become a real challenge to global scientists.

Conventional methods like nanofilteration [1], ozonation [2], solar-assisted photocatalytic degradation [3], precipitation [4], and electrochemical methods [5] are employed for removal of toxic dyes from wastewater. However, most of these methods suffer from one or more limitations. Among all the available physical or chemical methods of water treatment, only the adsorption technique is measured as most efficient and adaptable in practice. For a long time activated carbon was considered as an effective

\footnotetext{
* Corresponding author. Address: King Fahd University of Petroleum and Minerals, Dhahran, Saudi Arbia. Fax: +91 1332273560.

E-mail addresses: vinodfcy@iitr.ernet.in, vinodfcy@gmail.com (V.K. Gupta).
}

adsorbent but the high cost of activated carbon has stimulated interest in examining the feasibility of using cheaper waste materials as potential adsorbents. Thus materials like beech sawdust [6], silkworm pupa [7], waste apricot [8], natural zeolite [9], Leacril fabric [10], pumice powder [11], and agricultural wastes [12] have been utilized for removal of water-soluble toxic dying materials from contaminated water. Recent significant contributions have been made by Wang and co-workers by developing coal ash, fly ash, red mud, etc. into potential adsorbents for the removal of dyes and heavy metals [13-17]. In the past few years our laboratory has developed versatile and cost-effective methods for decolorizing wastewater by employing some waste materials [18-22]. The present study is yet another attempt to explore the possibility of utilizing bottom ash and deoiled soya as economic and effective adsorbents for the removal of a hazardous coloring agent, carmoisine $A$, from wastewaters.

Carmoisine A (Fig. 1) is a synthetic azo class of dye, imparting red color to foods. Being a typical azo dye the effluent containing carmoisine $A$ is also difficult to treat in environmental systems due to the sulfonic group, which makes it polar and soluble in water. In analytical chemistry laboratories it is widely used in photometric determination of $\mathrm{Mg}, \mathrm{Pd}, \mathrm{Cu}, \mathrm{Sn}$, and $\mathrm{Cr}$. For many years it was used as coloring material for edibles like jams and preservatives; however, most of the developed countries finally prohibited its use in edibles 


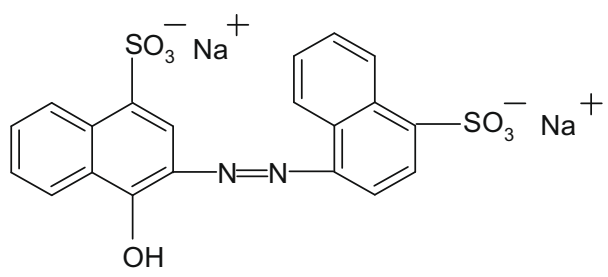

Fig. 1. Chemical structure of carmoisine A.

due to the presence of $\beta$-napthylamine, a well-known carcinogen, in it [23]. Moreover, like many azo dyes reductive cleavage of azo groups results into a carcinogenic aromatic amine [24,25]. The dye also causes asthma or drug intolerance, including nettle rash and water retention to many people. It boosts behavioral effects like hyperactivity, temper tantrums, and sleeplessness in children and high doses of the dye also result in somnolence, coma, convulsions, and even death [26]. It has also been well established that carmoisine $A$ and its metabolites inhibit true and pseudo-cholinesterase enzyme activity in human erythrocytes and plasma [27]. It is also identified as an electron-deficient xenobiotic compound, less susceptible to oxidative catabolism by bacteria. Consequently, carmoisine A tends to persist under aerobic environmental conditions [28]. The dye is also detected as causing chromosomal damage [29] and may also undergo reduction followed by a chain of reactions leading to formation of toxic components [30]. Thus, it is essential to focus the research in evaluating the adsorption potential of the adsorbents for removal of carmoisine A.

The adsorbents employed for present investigation are "bottom ash," a waste product of power generation plants, and "deoiled soya," a waste product produced at soya bean oil extracting mills. The bottom ash is a coarse, granular, incombustible by-product of power plants, obtained after combusting coke. It is an undesired collected material, whose disposal has always been a matter of concern to the station authorities, as the dumped ash makes the land infertile [31]. Deoiled soya is the waste material from soya oil industries, which is obtained after extracting all possible nutrients of soya beans. It is a porous and dry flaky material with brownish white color. Deoiled soya is being used as animal food but the reports suggest that more than $170 \mathrm{ppm}$ hexane residue in the deoiled soya makes it toxic to birds, animals, and fish [32].

Keeping all these in view it was found worthwhile to carry out a detailed study on the removal of the azo dye "carmoisine A." The present investigation deals with its batch and bulk removal through adsorption over two waste materials-bottom ash and deoiled soya in their activated forms.

\section{Materials and methods}

Water-soluble azo dye carmoisine $\mathrm{A}\left(\mathrm{C}_{20} \mathrm{H}_{12} \mathrm{~N}_{2} \mathrm{Na}_{2} \mathrm{O}_{7} \mathrm{~S}_{2}\right)$, IUPAC name disodium 4-hydroxy-3-(4-sulfonato-1-nephthylazo)-naphthalene-1-sulfonate (commonly known as C.I food red 3, azorubine, acid red 14, brilliant crimson red, etc.), was procured from $\mathrm{M} / \mathrm{s}$ Merck. All other chemicals were of A.R grade. All solutions employed in the study were prepared in double-distilled water.

The gray-black granular bottom ash was obtained from Bharat Heavy Electrical Limited, Bhopal, and deoiled soya was a gift from $\mathrm{M} / \mathrm{s}$ Sanwaria Agro Oils Limited, Bhopal. The $\mathrm{pH}$ of each solution was measured by using Microprocessor-based pH meter; Model HI 8424 (M/s Henna Instruments, Italy) and absorbance measurements were carried out on UV/vis spectrophotometer Model 117 $(\mathrm{M} / \mathrm{s}$ Systronics, Ahmedabad, India) over the wavelength range 400-600 nm. Scanning electron microscopic studies were carried out using a Philips SEM 501 electron microscope and a Philips X- ray diffractophotometer was employed for X-ray measurements. Quantasorb Model QS-7 surface area analyzer, mercury porosimeter, and specific gravity bottles determined related physical characteristics of the adsorbents.

\subsection{Material development}

Adsorbents bottom ash and deoiled soya were first washed with double-distilled water and dried. To remove the adhering organic impurities, dried materials were then dipped in hydrogen peroxide $(20 \% \mathrm{v} / \mathrm{v})$ for $24 \mathrm{~h}$. Adsorbents were then washed and dried in an oven for optimum time to remove moisture. Deoiled soya was sieved to desired particle size, while bottom ash was further activated in a furnace at $773 \mathrm{~K}$ and then sieved. Both adsorbents were stored separately in vacuum desiccators until required.

For batch adsorption, a series of $25 \mathrm{~mL}$ of $10 \times 10^{-5} \mathrm{~mol} \mathrm{~L}^{-1}$ of the solution was added with $0.1 \mathrm{~g}$ of bottom ash and $0.1 \mathrm{~g}$ of deoiled soya of particle size 36 BSS mesh (0.425-0.15 mm) each in $100-\mathrm{mL}$ volumetric flasks and the solution is mechanically shaken for optimum time. The sample is then filtered and analyzed spectrophotometrically. The experiment is repeated at constant agitation speed and at room temperature with different particle sizes.

\subsection{Adsorption studies}

Batch adsorption studies of adsorbents bottom ash and deoiled soya were performed to understand the effect of various parameters like $\mathrm{pH}(2.50)$, temperatures $(303,313,323 \mathrm{~K})$, and adsorbate amount. A series of $100-\mathrm{mL}$ graduated volumetric flasks containing equal volumes of adsorbate solutions at different concentrations were employed at desired $\mathrm{pH}$. An appropriate amount of adsorbents of a particular particle size was added into each flask separately and was mechanically agitated. The solution was then filtered using Whatman filter paper (No. 41) and the uptake of the dye was monitored spectrophotometrically by measuring absorbance at $\lambda_{\max } 508 \mathrm{~nm}$.

\subsection{Kinetic studies}

For examining the rate and the equilibrium data, a series of $25 \mathrm{~mL}$ solution of carmoisine A of known concentration and a known amount of adsorbent were taken together in airtight 100$\mathrm{mL}$ conical flasks. The whole mixture flasks were kept in a water bath, at a desired temperature, and were agitated periodically. After a definite interval of time, the solution of flasks was filtered and the filterate of each was evaluated spectrophotometrically for the uptake of the dye.

\subsection{Column studies}

The practical implications of the adsorption technique were assessed through column operations. Two glass columns $(30 \times 1 \mathrm{~cm})$ were filled separately with an appropriate amount of bottom ash and deoiled soya, of mesh size $100(0.15-0.08 \mathrm{~mm})$ and 36 BSS mesh $(0.425-0.15 \mathrm{~mm})$, respectively. The primary procedure demands preparation of slurry in water, which diminishes air entrapment in the column [33]. The slurry was then fed into the column supported by a glass wool. Each column was then loaded with an adsorbate solution of known concentration, which was percolated through the column at a constant flow rate $(0.05 \mathrm{~mL} /$ min). The effluent concentration was analyzed spectrophotometrically at $\lambda_{\max } 508 \mathrm{~nm}$. The column was operated till the runoff concentration matches the original concentration of the loaded dye. Elution with a suitable solvent like sodium hydroxide solution ( $\mathrm{pH}$ 13) was performed through the exhausted column, for regeneration and recovery of the adsorbent. 


\section{Results and discussion}

\subsection{Characterization of adsorbents}

Conventional chemical as well as analytical techniques were employed to ascertain different characteristics of adsorbents. The chemical constituents of bottom ash and deoiled soya are given in Table 1 . The physical characteristics such as porosity and density were determined using a mercury porosimeter and specific gravity bottles, respectively (Table 1 ). The acidic nature of adsorbents was ascertained by keeping $1 \mathrm{~g}$ of both adsorbents separately in $25 \mathrm{~mL}$ distilled water of $\mathrm{pH} 7.0$ for $24 \mathrm{~h}$ in an airtight container. The decrease in the $\mathrm{pH}$ value of the filtrate confirms the nature of both adsorbents as acidic.

The thermal stability of bottom ash was confirmed by the DTA curves. The d-spacing values were provided by the X-ray spectrum of the adsorbents, which reveals the presence of mainly alumina $\left(\mathrm{Al}_{2} \mathrm{O}_{3}\right)$, gypsum $\left(\mathrm{CaSO}_{4} \cdot 2 \mathrm{H}_{2} \mathrm{O}\right)$, beverite $\left[\mathrm{Pb}(\mathrm{Cu}, \mathrm{Fe}, \mathrm{Al})_{3}\left(\mathrm{SO}_{4}\right)_{2}\right.$ $\left.(\mathrm{OH})_{6}\right]$, borax $\left(\mathrm{Na}_{2} \mathrm{~B}_{4} \mathrm{O}_{7} \cdot 10 \mathrm{H}_{2} \mathrm{O}\right)$, and kaolinite $\left[2\left(\mathrm{Al}_{2} \mathrm{Si}_{2} \mathrm{O}_{5}(\mathrm{OH})_{4}\right)\right]$. For deoiled soya, the XRD spectrum does not give any major peak(s) which could be due to lack of inorganic substances in the activated deoiled soya.

Both adsorbents were analyzed using infrared spectrophotometric study. Bottom ash exhibited a sharp absorption band in the region of $3700-3500 \mathrm{~cm}^{-1}$. The bands at $3467,2930,2676$, 1502,1097 , and $790 \mathrm{~cm}^{-1}$ indicated the presence of laumonite, amber, mulite, azurite, bavenite, and kaolinite, respectively, in bottom ash. For deoiled soya, the bands obtained at 479, 779, 1113, and $3459 \mathrm{~cm}^{-1}$ indicated the presence of gorthite $(4[\mathrm{FeO} \cdot \mathrm{OH}])$, coesite $\left(\mathrm{SiO}_{2}\right)$, corundum $\left(2\left[\alpha-\mathrm{Al}_{2} \mathrm{O}_{3}\right]\right)$, and laumonite $\left(4\left[\mathrm{CaAl}_{2}\right.\right.$ $\left.\left.\mathrm{Si}_{4} \mathrm{O}_{12} \cdot 4 \mathrm{H}_{2} \mathrm{O}\right]\right)$, respectively.

\subsection{Adsorption studies}

\subsubsection{Effect of $p H$}

The $\mathrm{pH}$ of the dye solution plays an important role in the adsorption capacity of any adsorbent. In order to determine the adsorption behavior of the dye, tests were carried out under constant experimental conditions taking the initial dye concentration

Table 1

Chemical constituents and physical parameters of the adsorbents.

\begin{tabular}{|c|c|c|c|c|}
\hline \multicolumn{2}{|l|}{ Bottom ash } & \multicolumn{3}{|l|}{ Deoiled soya } \\
\hline \multirow{2}{*}{$\frac{\text { Constituents }}{\text { Moisture }}$} & Percentage by weight & Constituents & \multicolumn{2}{|c|}{ Percentage by weight } \\
\hline & 15 & Moisture & 11 & \\
\hline $\mathrm{SiO}_{2}$ & 45.4 & $\mathrm{SiO}_{2}$ & 6 & \\
\hline $\mathrm{Al}_{2} \mathrm{O}_{3}$ & 10.3 & Fiber & 2 & \\
\hline $\mathrm{Fe}_{2} \mathrm{O}_{3}$ & 9.7 & $\mathrm{Ca}$ & 0. & \\
\hline $\mathrm{CaO}$ & 15.3 & $\mathrm{P}$ & 0. & \\
\hline $\mathrm{MgO}$ & 3.1 & Profat & 48 & \\
\hline Parameter & \multicolumn{2}{|c|}{ Bottom ash } & & Deoiled soya \\
\hline Porosity (\%) & \multicolumn{2}{|c|}{46} & & 67 \\
\hline Density $\left(\mathrm{g} \mathrm{mL}^{-1}\right.$ & \multicolumn{2}{|c|}{0.6301} & & 0.5614 \\
\hline Nature & \multicolumn{2}{|c|}{ Acidic } & & Acidic \\
\hline
\end{tabular}

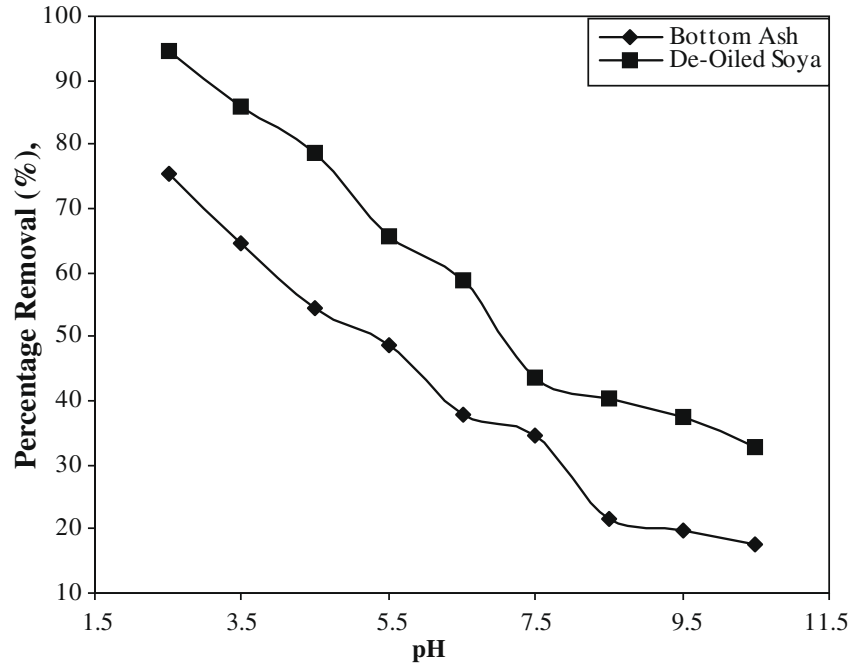

Fig. 2. Effect of pH on adsorption of carmoisine A over bottom ash and deoiled soya at $303 \mathrm{~K}$. Bottom ash: concentration $=10 \times 10^{-5} \mathrm{~mol} \mathrm{~L}^{-1}$, adsorbent dose $=0.1 \mathrm{~g}$ / $25 \mathrm{~mL}$, particle size $=0.15-0.08 \mathrm{~mm}$. Deoiled soya: concentration $=10 \times 10^{-5} \mathrm{~mol} \mathrm{~L}^{-1}$, adsorbent dose $=0.1 \mathrm{~g} / 25 \mathrm{~mL}$, particle size $=0.425$ $0.15 \mathrm{~mm}$.

as $10 \times 10^{-5} \mathrm{~mol} \mathrm{~L}^{-1}$. The $\mathrm{pH}$ of the test solutions was adjusted using $\mathrm{NaOH}$ and $\mathrm{HCl}$. The variation of dye adsorption on adsorbents over a wide range of $\mathrm{pH}$ is depicted in Fig. 2 . The results indicate that the extent of adsorption of the dye is affected significantly with $\mathrm{pH}$ due to its affect on surface binding site of the adsorbent and the ionization process of the dye molecules. For bottom ash and deoiled soya the adsorption capacity decreases constantly with increase in $\mathrm{pH}$ from 2.50 to 10.50 . The percentage removal at lower $\mathrm{pH}$ was almost $75 \%$ and $95 \%$ for bottom ash and deoiled soya, respectively. Since both adsorbents show high adsorption under acidic conditions, an optimum pH 2.50 was selected for further investigations. The higher adsorption of the dye at low $\mathrm{pH}$ is due to increased protonation by neutralization of the negative charge at the surface of the adsorbents. This helps in the preference of the dye for active sites and facilitates the diffusion process. While, with increase in alkaline conditions or $\mathrm{pH}$, protonation is reduced, thereby retarding diffusion and adsorption.

\subsubsection{Effect of particle size}

The effect of particle size on adsorption of the dye on bottom ash and deoiled soya was investigated by evaluating the adsorption capacities of the adsorbents. Table 2 reveals that with increase in mesh size adsorption increases. This can be attributed to the fact that the smaller adsorbent particles have shortened diffusion paths and increased total surface area, and therefore, the ability to penetrate all internal pore structures of adsorbent is very high. For further studies, $0.425-0.15 \mathrm{~mm}$ (36 BSS mesh size) for deoiled soya and $0.15-0.08 \mathrm{~mm}$ (100 BSS mesh size) for bottom ash were chosen, based on their adsorption capacities and availability of the amount of adsorbents.

Table 2

Effect of sieve size of different adsorbents on the rate of adsorption of carmoisine A over bottom ash and deoiled soya.

\begin{tabular}{|c|c|c|c|c|}
\hline \multirow[t]{2}{*}{ Mesh size } & \multicolumn{2}{|l|}{ Bottom ash } & \multicolumn{2}{|l|}{ Deoiled soya } \\
\hline & Amount adsorbed $\times 10^{-5}\left(\mathrm{~mol} \mathrm{~g}^{-1}\right)$ & $k\left(\mathrm{~h}^{-1}\right)$ & Amount adsorbed $\times 10^{-5}\left(\mathrm{~mol} \mathrm{~g}^{-1}\right)$ & $k\left(\mathrm{~h}^{-1}\right)$ \\
\hline $36(0.425-0.15 \mathrm{~mm})$ & 0.970 & 0.037 & 1.450 & 0.036 \\
\hline $100(0.15-0.08 \mathrm{~mm})$ & 1.092 & 0.024 & 1.532 & 0.040 \\
\hline $170(\leqslant 0.08 \mathrm{~mm})$ & 1.460 & 0.020 & 1.587 & 0.042 \\
\hline
\end{tabular}

Concentration $=10 \times 10^{-5} \mathrm{~mol} \mathrm{~L}^{-1}, \mathrm{pH} 2.50$, temperature $=303 \mathrm{~K}$, adsorbent dose $=0.1 \mathrm{~g} / 25 \mathrm{~mL}$ (bottom ash) and $0.1 \mathrm{~g} / 25 \mathrm{~mL}($ deoiled soya). 


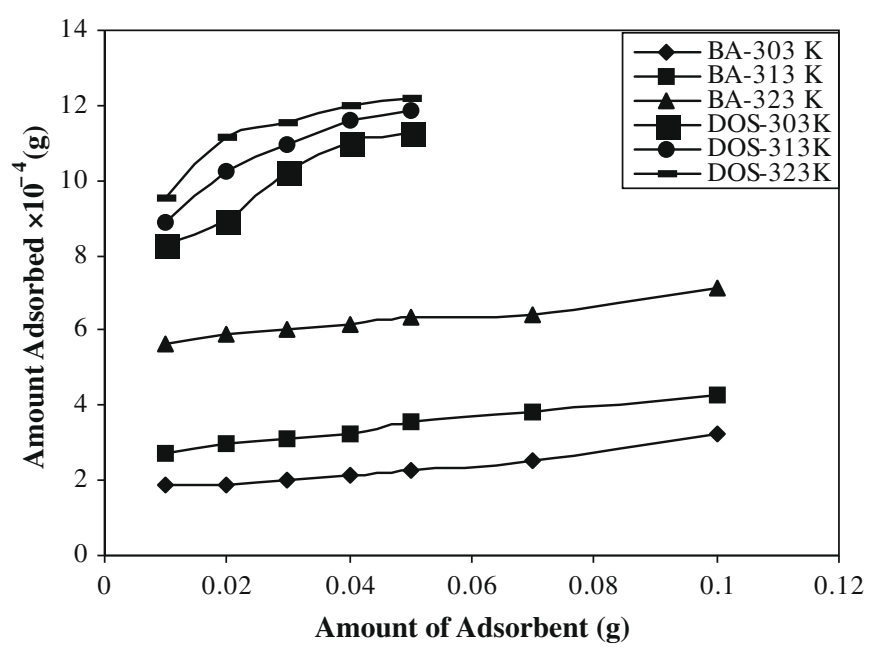

Fig. 3. Effect of amount of adsorbent on uptake of carmoisine A over bottom ash and deoiled soya at different temperatures. Dye concentration $=10 \times 10^{-5} \mathrm{~mol} \mathrm{~L}^{-1}$, particle size $=0.15-0.08 \mathrm{~mm}$ (bottom ash), and $0.425-0.15 \mathrm{~mm}$ (deoiled soya), $\mathrm{pH}$ 2.50 .

\subsubsection{Effect of adsorbent dose}

Fig. 3 show the amount of dye removed as a function of adsorbent dosage at $10 \times 10^{-5} \mathrm{~mol} \mathrm{~L}^{-1}$ of initial dye concentration and at different temperatures for bottom ash and deoiled soya. Adsorbent dosage was varied from $0.01 \mathrm{~g} / 25 \mathrm{~mL}$ to $0.1 \mathrm{~g} / 25 \mathrm{~mL}$ for bottom ash and $0.01 \mathrm{~g} / 25 \mathrm{~mL}$ to $0.05 \mathrm{~g} / 25 \mathrm{~mL}$ for deoiled soya. The figure clearly indicates that amount of adsorption of the dye increases with increase in adsorbent quantity. Such a trend is mainly due to increase in sportive surface area and availability of more adsorption sites. Thus, $0.1 \mathrm{~g} / 25 \mathrm{~mL}$ of bottom ash and $0.05 \mathrm{~g} / 25 \mathrm{~mL}$ of deoiled soya were chosen as optimum dosage for carmoisine A removal. It is also interesting to note that the uptake of the dye increases marginally as the temperature is raised from 303 to $323 \mathrm{~K}$

\subsubsection{Effect of concentration of adsorbate}

The effect of initial dye concentration on the adsorption process for carmoisine A-bottom ash and carmoisine A-deoiled soya was explored at concentration range from $1 \times 10^{-5}$ to $10 \times 10^{-5} \mathrm{~mol} \mathrm{~L}^{-1}$ at a fixed $\mathrm{pH}$ and at different temperatures (303, 313, and $323 \mathrm{~K}$ ). It is evident from Fig. 4 that the amount of dye adsorbed per unit mass of adsorbent increases from $0.160 \times 10^{-5}$ to $1.962 \times 10^{-5} \mathrm{~mol} \mathrm{~g}^{-1}$ for bottom ash and from $0.40 \times 10^{-5}$ to $3.13 \times 10^{-5} \mathrm{~mol} \mathrm{~g}^{-1}$ for deoiled soya at $323 \mathrm{~K}$. This indicates that increase in concentration of the dye decreases the resistance toward dye uptake and increases the mass driving force among adsorbent and adsorbate, which increases the percentage adsorption of the dye.

\subsubsection{Effect of contact time}

In order to determine the equilibrium time for maximum uptake, a contact time study was performed. Batch experiments were carried out for different contact times with a fixed adsorbent dose at pH 2.50 and at different temperatures $(303,313$, and $323 \mathrm{~K})$. Initial studies reveal that at $323 \mathrm{~K}$ within the first $30 \mathrm{~min}$ of contact the amount of carmoisine A adsorbed is almost $35 \%$ and $40 \%$ over bottom ash and deoiled soya, respectively. A graphical representation of contact time as a function of initial concentration $\left(10 \times 10^{-5} \mathrm{~mol} \mathrm{~L}^{-1}\right)$ as given in Fig. 5 suggests instantaneous adsorption rate, leading gradually to optimal removal within $5 \mathrm{~h}$ and $4 \frac{1}{2} \mathrm{~h}$ for bottom ash and deoiled soya, respectively. As vindicated in Fig. 5, after reaching the saturation value a continuous

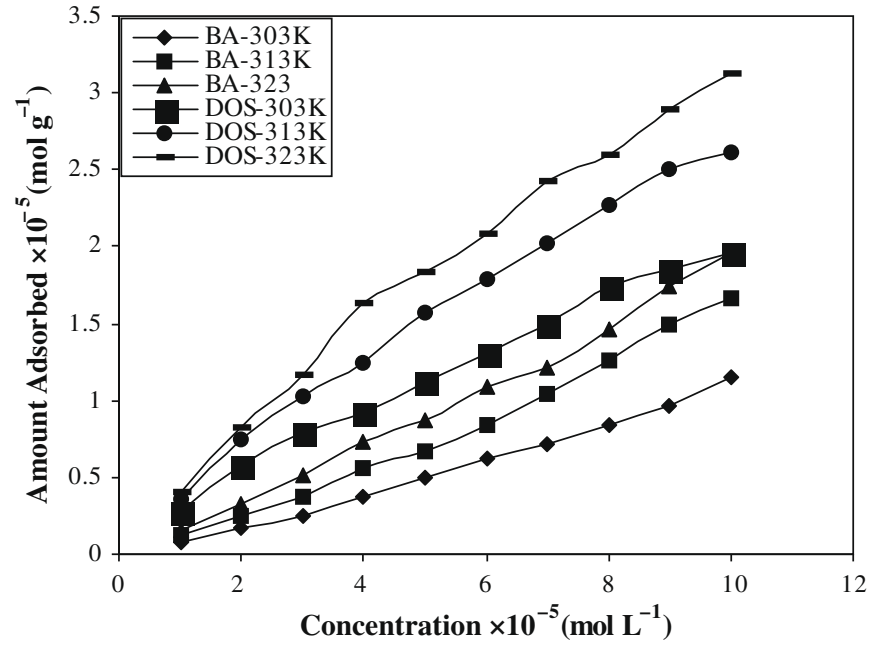

Fig. 4. Effect of concentration of carmoisine $A$ on adsorption over bottom ash and deoiled soya at different temperatures. Adsorbent dose $=0.1 \mathrm{~g} / 25 \mathrm{~mL}$ (bottom ash) and $0.05 \mathrm{~g} / 25 \mathrm{~mL}$ (deoiled soya), particle size $=0.15-0.08 \mathrm{~mm}$ (bottom ash) and $0.425-0.15 \mathrm{~mm}$ (deoiled soya), $\mathrm{pH} 2.50$.

and smooth curve is obtained at each temperature for both adsorbents. The difference in the equilibrium time for both adsorbents may be due to difference in pore size and properties of pores of the adsorbents, while decrease in rate of removal of dye with time may be attributed to the decrease in the diffusion layer thickness surrounding the adsorbent particles.

\subsection{Adsorption models}

The equilibrium sorption isotherm is fundamentally very decisive in design of any sorption system. The equilibrium relationships between adsorbent and adsorbate are described by sorption isotherms. The adsorption of carmoisine $A$ onto both adsorbents was studied at initial dye concentration $10 \times 10^{-5} \mathrm{~mol} \mathrm{~L}^{-1}$, different temperatures $(303,313$, and $323 \mathrm{~K}$ ), and time intervals. In the present work equilibrium adsorption data were described using well-known Freundlich, Langmuir, Tempkin, and DubininRadushkevich (D-R) isotherm models.

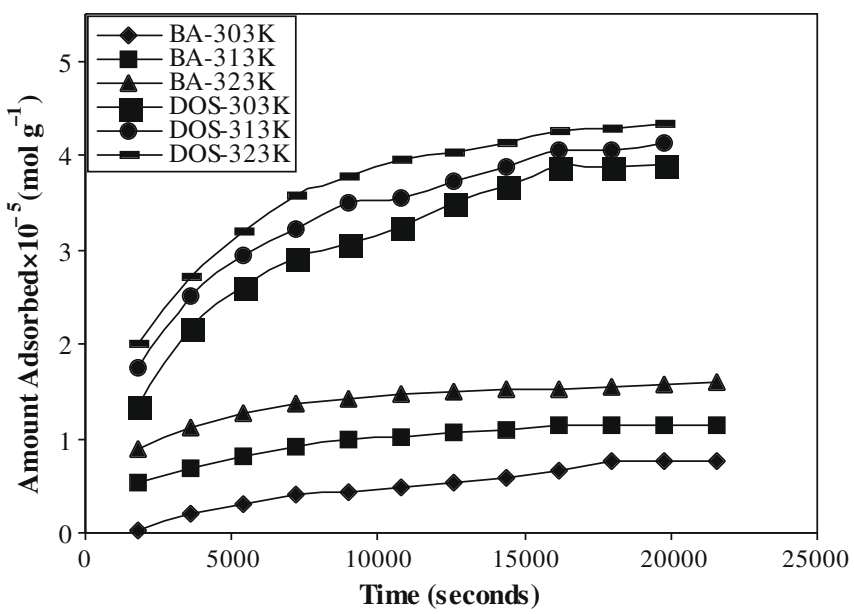

Fig. 5. Effect of contact time on the uptake of carmoisine A by bottom ash and deoiled soya at different temperatures. Adsorbent dose $=0.1 \mathrm{~g} / 25 \mathrm{~mL}$ (bottom ash) and $0.05 \mathrm{~g} / 25 \mathrm{~mL}$ (deoiled soya), particle size $=0.15-0.08 \mathrm{~mm}$ (bottom ash) and 0.425-0.15 mm (deoiled soya), pH 2.50. 


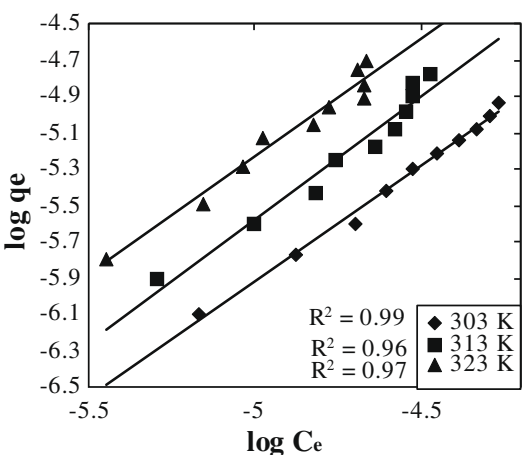

BA

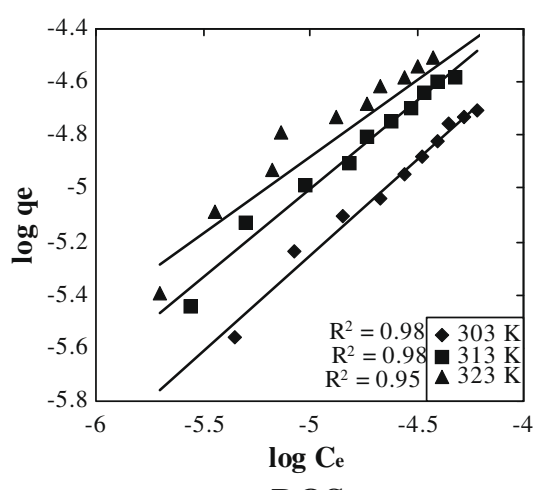

DOS

Fig. 6. Freundlich adsorption isotherm for adsorption of carmoisine A over bottom ash and deoiled soya at pH 2.50 .

\subsubsection{Freundlich adsorption isotherm model}

The Freundlich isotherm is an empirical model that considers heterogeneous adsorption energies on the adsorbent surface [34]. The linear form of Freundlich adsorption model is given by following relation:

$\log q_{\mathrm{e}}=\log K_{\mathrm{F}}+\frac{1}{n} \log C_{\mathrm{e}}$,

where $q_{\mathrm{e}}$ is the amount adsorbed $\left(\mathrm{mol} \mathrm{g}^{-1}\right)$, and $C_{\mathrm{e}}$ is the equilibrium concentration of the adsorbate $\left(\mathrm{mol} \mathrm{L}^{-1}\right) . K_{\mathrm{F}}$ and $n$, the Freundlich constants, are related to adsorption capacity and adsorption intensity, respectively. The linear plots of $\log C_{\mathrm{e}}$ versus $\log q_{\mathrm{e}}$ (Fig. 6) clearly reveal that adsorption of dye on bottom ash and deoiled soya follows the Freundlich model. The values of $K_{\mathrm{F}}$ and $n$ were derived from the intercepts and slope, respectively, and are listed in Table 3.

\subsubsection{Langmuir adsorption isotherm model}

The Langmuir sorption model assumes that uptake of adsorbate occurs on a homogeneous surface by monolayer adsorption without any interaction between the adsorbed ions. It also considers that there is no transmigration of the adsorbate in the plane of the surface of the adsorbent. The mathematical form of the Langmuir equation can be expressed as $[35,36]$

$\frac{1}{q_{\mathrm{e}}}=\frac{1}{Q_{\mathrm{o}}}+\frac{1}{b Q_{\mathrm{o}} C_{\mathrm{e}}}$,

where $q_{\mathrm{e}}$ is the amount of carmoisine A adsorbed $\left(\mathrm{mol} \mathrm{g}^{-1}\right), C_{\mathrm{e}}$ is the equilibrium molar concentration of the dye $\left(\mathrm{mol} \mathrm{L}^{-1}\right), Q_{0}$ is the maximum adsorption capacity $\left(\mathrm{mol} \mathrm{g}^{-1}\right)$, and $b$ is the energy of adsorption $\left(\mathrm{L} \mathrm{mol}^{-1}\right)$. The Langmuir constants were calculated from
Table 3

Freundlich and Langmuir constants for removal of carmoisine A at different temperatures and $\mathrm{pH} 2.50$.

\begin{tabular}{|c|c|c|c|c|c|c|}
\hline \multirow[t]{3}{*}{ Adsorbent } & \multicolumn{6}{|c|}{ Freundlich constants } \\
\hline & \multicolumn{3}{|l|}{$n$} & \multicolumn{3}{|l|}{$K_{\mathrm{F}}$} \\
\hline & $303 \mathrm{~K}$ & $313 \mathrm{~K}$ & $323 \mathrm{~K}$ & $303 \mathrm{~K}$ & $313 \mathrm{~K}$ & $323 \mathrm{~K}$ \\
\hline Bottom ash & 0.783 & 0.735 & 0.768 & 2.931 & 16.780 & 18.724 \\
\hline \multirow[t]{4}{*}{ Deoiled soya } & 1.389 & 1.508 & 1.564 & 0.022 & 0.021 & 0.023 \\
\hline & \multicolumn{6}{|c|}{ Langmuir constants } \\
\hline & \multicolumn{3}{|c|}{$Q_{0} \times 10^{-5}\left(\mathrm{~mol} \mathrm{~g}^{-1}\right)$} & \multicolumn{3}{|c|}{$\mathrm{b} \times 10^{4}\left(\mathrm{~L} \mathrm{~mol}^{-1}\right)$} \\
\hline & $303 \mathrm{~K}$ & $313 \mathrm{~K}$ & $323 \mathrm{~K}$ & $303 \mathrm{~K}$ & $313 \mathrm{~K}$ & $323 \mathrm{~K}$ \\
\hline Bottom ash & 1.210 & 1.600 & 1.780 & 0.911 & 1.382 & 2.312 \\
\hline Deoiled soya & 3.516 & 3.942 & 5.615 & 1.950 & 3.766 & 4.041 \\
\hline
\end{tabular}

Adsorbent dose $=0.1 \mathrm{~g} / 25 \mathrm{~mL}$ (bottom ash) and $0.05 \mathrm{~g} / 25 \mathrm{~mL}$ (deoiled soya).

the slopes and intercept of $1 / q_{\mathrm{e}}$ against $1 / C_{\mathrm{e}}$ that gives a straight line at each temperature, thereby confirming that the Langmuir isotherm is followed in the adsorption process (Fig. 7). The monolayer adsorption capacity, at $323 \mathrm{~K}$, was found to be $1.78 \times 10^{-5}$ and $5.62 \times 10^{-5} \mathrm{~mol} \mathrm{~g}^{-1}$ for bottom ash and deoiled soya, respectively. The obtained values of Langmuir constants are presented in Table 3. The essential feature of the Langmuir isotherm can be expressed by means of dimensionless constant separation factor, which is calculated using

$r=\frac{1}{1+b C_{0}}$,

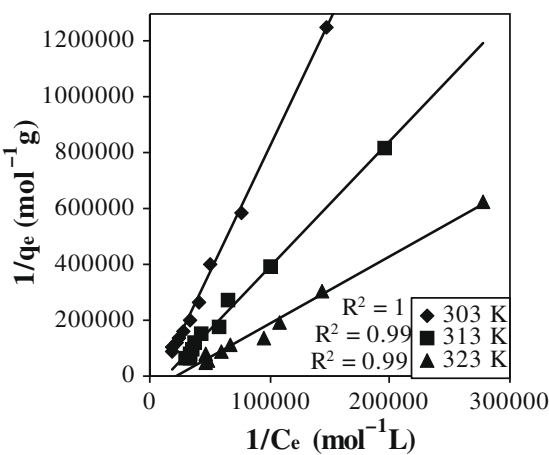

BA

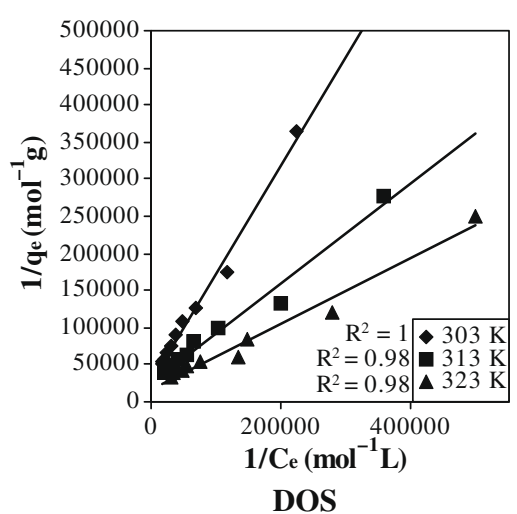

Fig. 7. Langmuir adsorption isotherm for adsorption of carmoisine A over bottom ash and deoiled soya at pH 2.50 . 
Table 4

Thermodynamic parameters for the uptake of carmoisine A at $\mathrm{pH} 2.50$.

\begin{tabular}{llllll}
\hline Adsorbent & \multicolumn{2}{c}{$\Delta G^{\circ}\left(\mathrm{kJ} \mathrm{mol}^{-1}\right)$} & & $\Delta H^{\circ}\left(\mathrm{kJ} \mathrm{mol}^{-1}\right)$ & $\Delta S^{\circ}\left(\mathrm{JK}^{-1} \mathrm{~mol}^{-1}\right)$ \\
\cline { 2 - 4 } & $303 \mathrm{~K}$ & $313 \mathrm{~K}$ & $323 \mathrm{~K}$ & & \\
\hline Bottom ash & 22.968 & 24.810 & 26.984 & 37.980 & 200.787 \\
Deoiled soya & 24.885 & 27.418 & 28.483 & 29.136 & 179.908
\end{tabular}

Adsorbent dose $=0.1 \mathrm{~g} / 25 \mathrm{~mL}$ (bottom ash) and $0.05 \mathrm{~g} / 25 \mathrm{~mL}$ (deoiled soya).

where $b$ denotes the Langmuir constant and $C_{0}$ the initial concentration [37]. The $r$ values have been found as $0.916,0.879$, and 0.812 for bottom ash and $0.837,0.726$, and 0.712 for deoiled soya at temperatures 303,313 , and $323 \mathrm{~K}$, respectively. It is clear from the data that the values of ' $r$ ' are less than unity at each temperature, which indicate favorable processes for both adsorbents at all the temperatures.

To study the effects of temperature and thermodynamic parameters, the change in enthalpy $\left(\Delta H^{\circ}\right)$, the change in entropy $\left(\Delta S^{\circ}\right)$, and the change in Gibb's free energy $\left(\Delta G^{\circ}\right)$ were also calculated for both adsorbents using following relations [38,39]:

$\Delta G^{\circ}=-R T \ln b$,

$\Delta H^{\circ}=-R\left(\frac{T_{2} T_{1}}{\left(T_{2}-T_{1}\right)}\right) \times \ln \left(\frac{b_{2}}{b_{1}}\right)$,

$\Delta S^{\circ}=\frac{\Delta H^{\circ}-\Delta G^{\circ}}{T}$,

where $b, b_{1}$, and $b_{2}$ are Langmuir constants at different temperatures.

The calculated values of thermodynamic parameters are presented in Table 4 . The negative free energy values suggest the feasibility of the process in both cases. The positive value of $\Delta \mathrm{H}^{\circ}$ indicates the endothermic nature for carmoisine A-bottom ash and carmoisine A-deoiled soya system, while positive values of entropy change $\left(\Delta S^{\circ}\right)$ show increased randomness of the process in each case.

\subsubsection{Tempkin adsorption isotherm model}

The Tempkin model [40] assumes a linear decrease in heat of adsorption with surface coverage and its linearized form is expressed as

$q_{\mathrm{e}}=k_{1} \ln k_{2}+k_{1} \ln C_{\mathrm{e}}$

where $q_{\mathrm{e}}$ is the amount of adsorbate adsorbed per unit mass of adsorbent at equilibrium $\left(\mathrm{mol} \mathrm{g}^{-1}\right), C_{\mathrm{e}}$ is the final concentration at equilibrium ( $\mathrm{mol} \mathrm{L}^{-1}$ ), $k_{1}$ is the Tempkin isotherm energy constant $\left(\mathrm{L} \mathrm{mol}^{-1}\right)$, and $k_{2}$ is the Tempkin isotherm constant. The isotherms verifying the Tempkin model obtained for bottom ash and deoiled
Table 5

Tempkin and D-R isotherm parameters for adsorption of carmoisine A over bottom ash and deoiled soya at $\mathrm{pH} 2.50$.

\begin{tabular}{llllll}
\hline & \multicolumn{2}{l}{ Bottom ash } & & \multicolumn{2}{c}{ Deoiled soya } \\
\cline { 2 - 3 } \cline { 5 - 6 } Tempkin isotherm & $k_{1}\left(\mathrm{~L} \mathrm{~mol}^{-1}\right)$ & $k_{2}$ & & $k_{1}\left(\mathrm{~L} \mathrm{~mol}^{-1}\right)$ & $k_{2}$ \\
\hline $303 \mathrm{~K}$ & $5 \times 10^{-6}$ & $16.28 \times 10^{4}$ & & $6 \times 10^{-6}$ & $59.72 \times 10^{4}$ \\
$313 \mathrm{~K}$ & $8 \times 10^{-6}$ & $8.08 \times 10^{4}$ & $8 \times 10^{-6}$ & $26.83 \times 10^{4}$ \\
$323 \mathrm{~K}$ & $9 \times 10^{-6}$ & $6.62 \times 10^{4}$ & $9 \times 10^{-6}$ & $6.62 \times 10^{4}$ \\
D-R isotherm & $\beta\left(\mathrm{mol}^{2} \mathrm{~J}^{-2}\right)$ & $\ln X_{\mathrm{m}}$ & & $\beta\left(\mathrm{mol}^{2} \mathrm{~J}^{-2}\right)$ & $\ln X_{\mathrm{m}}$ \\
\hline $303 \mathrm{~K}$ & $9 \times 10^{-9}$ & -5.813 & & $5 \times 10^{-9}$ & -7.723 \\
$313 \mathrm{~K}$ & $9 \times 10^{-9}$ & -4.802 & & $4 \times 10^{-9}$ & -7.612 \\
$323 \mathrm{~K}$ & $8 \times 10^{-9}$ & -4.567 & & $4 \times 10^{-9}$ & -7.437 \\
\hline
\end{tabular}

Adsorbent dose $=0.1 \mathrm{~g} / 25 \mathrm{~mL}$ (bottom ash) and $0.05 \mathrm{~g} / 25 \mathrm{~mL}$ (deoiled soya).

soya adsorption are exhibited in Fig. 8 and the calculated values of the Tempkin constants are presented in Table 5 .

\subsubsection{Dubinin-Radushkevich ( $D-R$ ) adsorption isotherm model}

The adsorption data have also been analyzed to distinguish between chemical and physical adsorption based on the heterogeneous characteristics of the adsorbents. The D-R model $[41,42]$ is expressed as

$\ln C_{\mathrm{ads}}=\ln X_{\mathrm{m}}-\beta \in^{2}$,

where $C_{\text {ads }}$ is the amount of dye adsorbed per unit weight of adsorbent $\left(\mathrm{mol} \mathrm{g}^{-1}\right), X_{\mathrm{m}}$ is the maximum adsorption capacity $\left(\mathrm{mol} \mathrm{g}^{-1}\right), \beta$ is the activity coefficient $\left(\mathrm{mol}^{2} \mathrm{~J}^{-2}\right.$ ) related to mean adsorption energy, and $\in$ is the Polanyi potential which is given as

$\epsilon=\mathrm{RT} \ln \left(1+\frac{1}{C_{\mathrm{e}}}\right)$,

where $R$ is universal gas constant $\left(\mathrm{J} \mathrm{mol}^{-1} \mathrm{~K}^{-1}\right), T$ is the temperature $(\mathrm{K})$, and $C_{\mathrm{e}}$ is the concentration at equilibrium $\left(\mathrm{mol} \mathrm{L}^{-1}\right)$.

The slopes of straight lines of graphs between $\ln C_{\text {ads }}$ against $\epsilon^{2}$ (Fig. 9) give activity coefficients and intercept yields adsorption capacity, which are presented in Table 5 . The mean sorption energy is the decisive factor for distinguishing between chemical and physical adsorption and is given by the form

$E=\frac{1}{\sqrt{ }-2 \beta}$.

The values of $E$ for carmoisine A-bottom ash and carmoisine A-deoiled soya are found to be 7.91 and $11.18 \mathrm{~kJ} \mathrm{~mol}^{-1}$, respectively, at $323 \mathrm{~K}$. The typical range of bonding energy for chemisorption is $8-16 \mathrm{~kJ} \mathrm{~mol}^{-1}$ [43]. Thus, the calculated values of $E$ suggest that chemisorption plays a significant role in adsorption process for both systems.
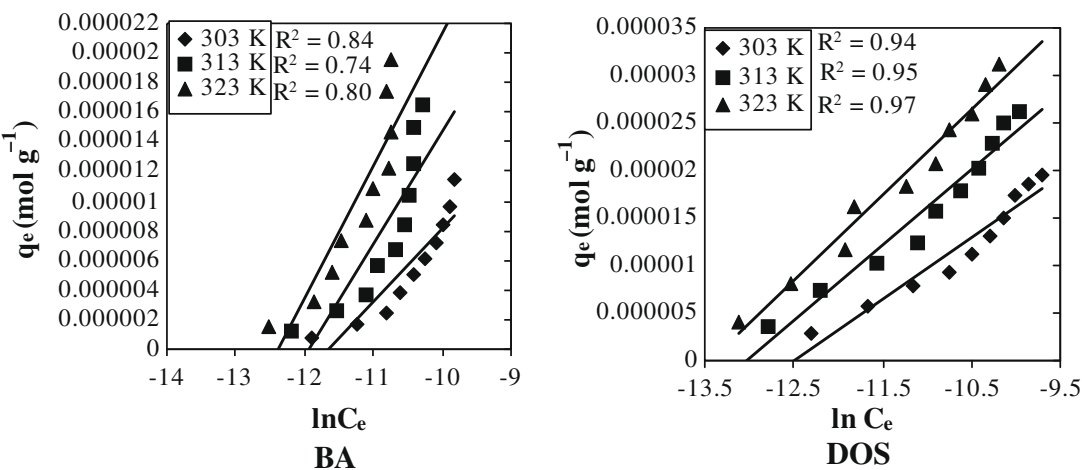

Fig. 8. Tempkin adsorption isotherms for adsorption of carmoisine A over bottom ash and deoiled soya at $\mathrm{pH} 2.50$ 

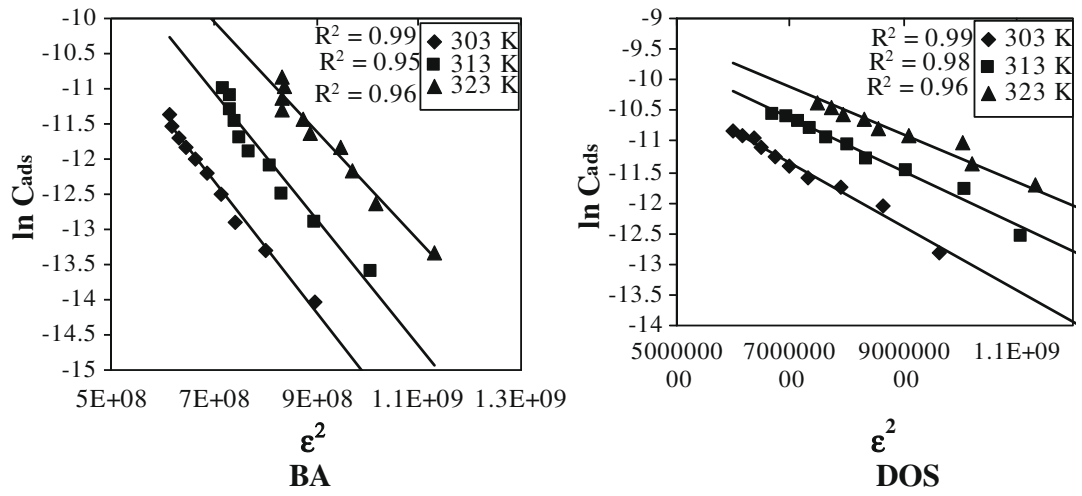

Fig. 9. D-R adsorption isotherm for adsorption of carmoisine A over bottom ash and deoiled soya at pH 2.50 .

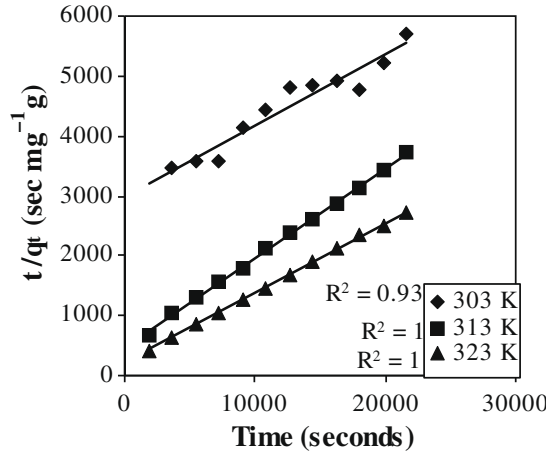

BA

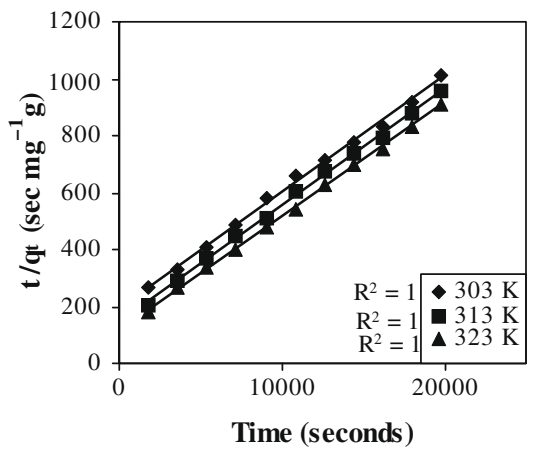

DOS

Fig. 10. Plot of time versus $t / q_{t}$ for adsorption of carmoisine A over bottom ash and deoiled soya at $\mathrm{pH} 2.50$.

\subsection{Kinetic modeling}

In order to monitor the kinetics of the adsorption of the dye over both adsorbents, a pseudo-second-order rate equation $[44,45]$ was applied. The specific rate constants for both systems were calculated using following mathematical form:

$\frac{t}{q_{t}}=\frac{1}{k_{2} q_{\mathrm{e}}^{2}}+\frac{t}{q_{\mathrm{e}}}$,

where $k_{2}$ is the rate constant and $q_{\mathrm{e}}$ and $q_{t}$ denote the amount adsorbed in $\mathrm{mg} \mathrm{g}^{-1}$ at equilibrium and at any time $t$, respectively. The values of $k_{2}$ and $q_{\mathrm{e}}$ were calculated from the intercept and slope of the linear plots of $t / q_{t}$ against $t$. Fig. 10 shows a graphical interpretation of the data for pseudo-second-order model. The results depicted in Table 6 show rate constant values for second order along with correlation coefficient of each straight line. Thus it is safe to conclude that the second-order rate expression is applicable in the both adsorption processes.

\subsubsection{Interpretation of kinetic dato}

For interpreting the experimental data, it is vital to identify the adsorption process steps, which govern the overall removal rate in each case. The mathematical treatment recommended by Boyd et al. [46] was employed to recognize whether the process is particle diffusion or film diffusion.

In order to institute the actual process involved in the adsorption of carmoisine A over bottom ash and deoiled soya and for quantitative treatment of the sorption dynamics the following expressions were employed:

$F=1-\frac{6}{\pi^{2}} \sum_{1}^{\infty}\left(1 / n^{2}\right) \exp \left(-n^{2} B_{t}\right)$

where $F$ is the fractional attainment of equilibrium at time $t, n$ is the Freundlich constant of the adsorbate, and $B_{t}$ is the time constant after time $t$;

$F=\frac{Q_{t}}{Q_{\infty}}$

Table 6

Kinetic parameters for removal of dye carmoisine A using bottom ash and deoiled soya at pH 2.50.

\begin{tabular}{|c|c|c|c|c|c|c|}
\hline \multirow[t]{2}{*}{ Pseudo-second order } & \multicolumn{3}{|l|}{ Bottom ash } & \multicolumn{3}{|l|}{ Deoiled soya } \\
\hline & $k_{2}\left(\mathrm{~g} \mathrm{mg}^{-1} \mathrm{~s}^{-1}\right)$ & $q_{\mathrm{e}}\left(\mathrm{mg} \mathrm{g}^{-1}\right)$ & $R^{2}$ & $k_{2}\left(\mathrm{~g} \mathrm{mg}^{-1} \mathrm{~s}^{-1}\right)$ & $q_{\mathrm{e}}\left(\mathrm{mg} \mathrm{g}^{-1}\right)$ & $R^{2}$ \\
\hline $303 \mathrm{~K}$ & $4.67 \times 10^{-6}$ & 8.45 & 0.93 & $8.50 \times 10^{-6}$ & 24.50 & 1 \\
\hline $313 \mathrm{~K}$ & $4.66 \times 10^{-5}$ & 6.71 & 1 & $1.20 \times 10^{-5}$ & 24.30 & 1 \\
\hline $323 \mathrm{~K}$ & $6.11 \times 10^{-5}$ & 8.63 & 1 & $1.41 \times 10^{-5}$ & 24.90 & 1 \\
\hline
\end{tabular}

Adsorbent dose $=0.1 \mathrm{~g} / 25 \mathrm{~mL}$ (bottom ash) and $0.05 \mathrm{~g} / 25 \mathrm{~mL}$ (deoiled soya) $\mathrm{pH} 2.50$. 


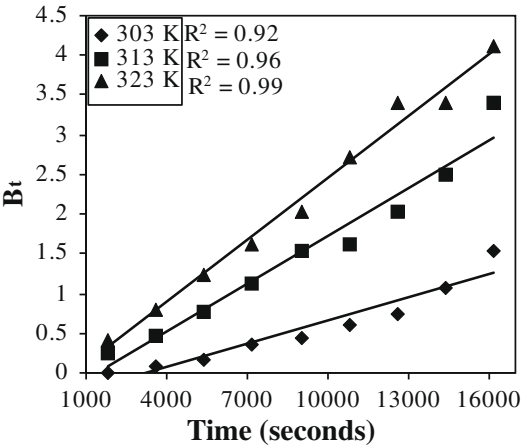

BA

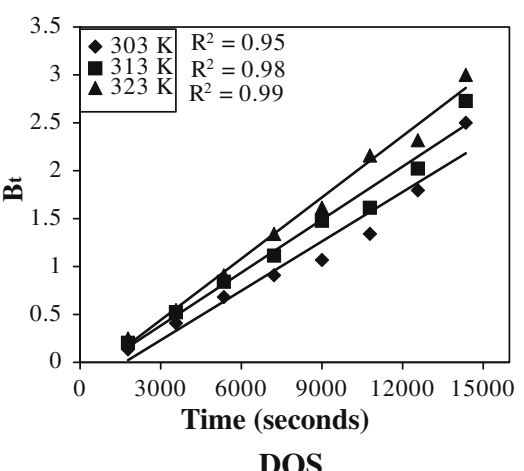

DOS

Fig. 11. Correlation of time versus $B_{t}$ for adsorption of carmoisine A over bottom ash and deoiled soya at $\mathrm{pH} 2.50$.

where $Q_{t}$ and $Q_{\infty}$ are amounts adsorbed $\left(\mathrm{mol} \mathrm{g}^{-1}\right)$ after time $t$ and after infinite time, respectively.

$B=\frac{\pi^{2} D_{\mathrm{i}}}{r_{0}^{2}}=$ time constant,

where $B$ is the time constant, $D_{\mathrm{i}}$ is the effective diffusion coefficient of adsorbate, and $r_{0}$ is the radius of spherical adsorbent particle.

Based on the values of fractional attainment, $B_{t}$ values were derived from Reichenberg's table [47]. In each case, a $B_{t}$ versus time graph was plotted to discriminate between the film diffusion and the particle diffusion adsorption rates. The pictorial presentation of the $B_{t}$ as function of time (Fig. 11) displays linearity with straight lines passing through the origin in case of adsorption of the dye over bottom ash and deoiled soya at different temperatures. The results clearly suggest that the rate-determining process is particle diffusion, where external transport of the ions is greater than the internal transport.

The slopes of $B_{t}$ versus time graph were employed to calculate the effective diffusion coefficient $\left(D_{\mathrm{i}}\right)$ values for both adsorbents at 303,313 , and $323 \mathrm{~K}$. Fig. 12 depicts the relationship between $1 /$ temperature and $\log D_{\mathrm{i}}$. The values of $D_{\mathrm{i}}$ are found to increase as temperature is elevated from 303 to $323 \mathrm{~K}$ and suggests an increased mobility of the ions due to decreased retarding force acting on diffusing ions with temperature rise. The energy of activation $\left(E_{\mathrm{a}}\right)$, entropy $\left(\Delta S^{\#}\right)$, and preexponential constant $\left(D_{\mathrm{o}}\right)$ values were calculated using the following equations and are depicted in Table 7:

$D_{\mathrm{i}}=D_{\mathrm{o}} \exp \left(-\frac{E_{\mathrm{a}}}{R T}\right)$

$D_{\mathrm{o}}=\left(2.72 d^{2} k T / h\right) \exp \frac{\Delta S^{\#}}{R}$,

where $d$ is the average distance between two successive sites of the adsorbent, $k$ is the Boltzmann constant $\left(\mathrm{J} \mathrm{K}^{-1}\right), h$ is the Plank constant $\left(\mathrm{J} \mathrm{K}^{-1}\right), T$ is the temperature $(\mathrm{K})$, and $R$ is the universal gas

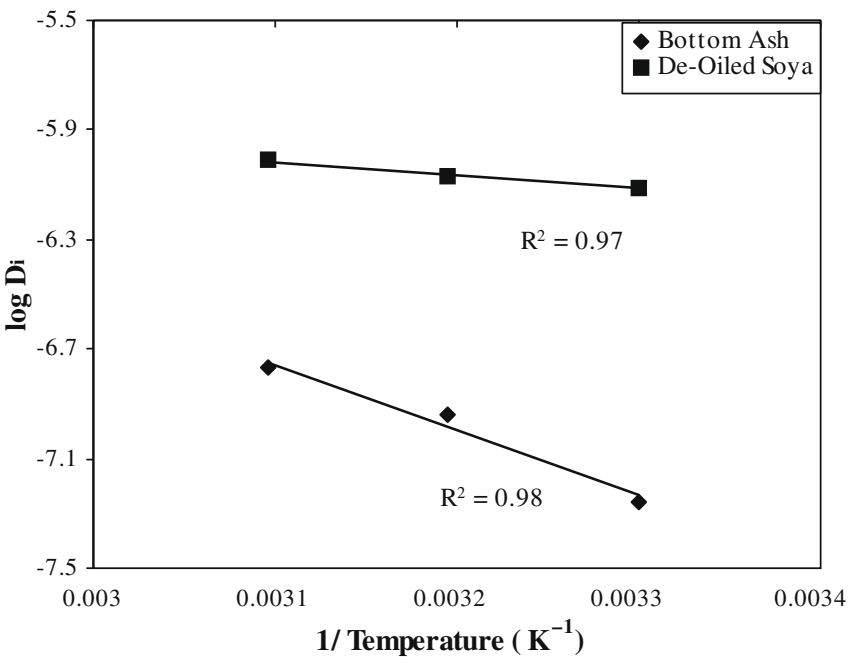

Fig. 12. Plot of 1 /temperature versus $\log D_{\mathrm{i}}$ for carmoisine $\mathrm{A}$-bottom ash system and carmoisine A-deoiled soya system at different temperatures.

constant $\left(\mathrm{J} \mathrm{K}^{-1} \mathrm{~mol}^{-1}\right)$. The negative values of $\Delta S^{\#}$ obtained for both systems reveal that the internal structure of the adsorbents does not go through any significant change during the adsorption of the dye.

\subsection{Mass transfer studies}

The molecular diffusion model suggested by McKay et al. [48] was employed to examine the effect of initial concentration and adsorbent dosage on the rate of mass transfer. The external mass transfer coefficient was evaluated by assuming that the adsorption from the bulk solution occurs onto an interior site. For studying mass transfer for adsorption of carmoisine A over bottom ash and deoiled soya the following equation was employed:

Table 7

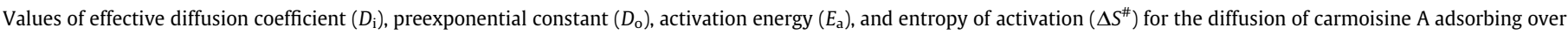
bottom ash and deoiled soya.

\begin{tabular}{|c|c|c|c|c|c|c|}
\hline \multirow[t]{2}{*}{ Adsorbent } & \multicolumn{3}{|c|}{$D_{\mathrm{i}} \times 10^{-7}$} & \multirow[t]{2}{*}{$D_{\mathrm{o}}$} & \multirow[t]{2}{*}{$E_{\mathrm{a}}\left(\mathrm{kJ} \mathrm{mol}^{-1}\right)$} & \multirow[t]{2}{*}{$\Delta S^{\#}\left(\mathrm{~J} \mathrm{~K}^{-1} \mathrm{~mol}^{-1}\right)$} \\
\hline & $303 \mathrm{~K}$ & $313 \mathrm{~K}$ & $323 \mathrm{~K}$ & & & \\
\hline Bottom ash & 0.56 & 1.14 & 1.71 & 4.81 & 45.98 & -190.76 \\
\hline Deoiled soya & 7.79 & 8.43 & 9.76 & 2.90 & 9.15 & -290.69 \\
\hline
\end{tabular}




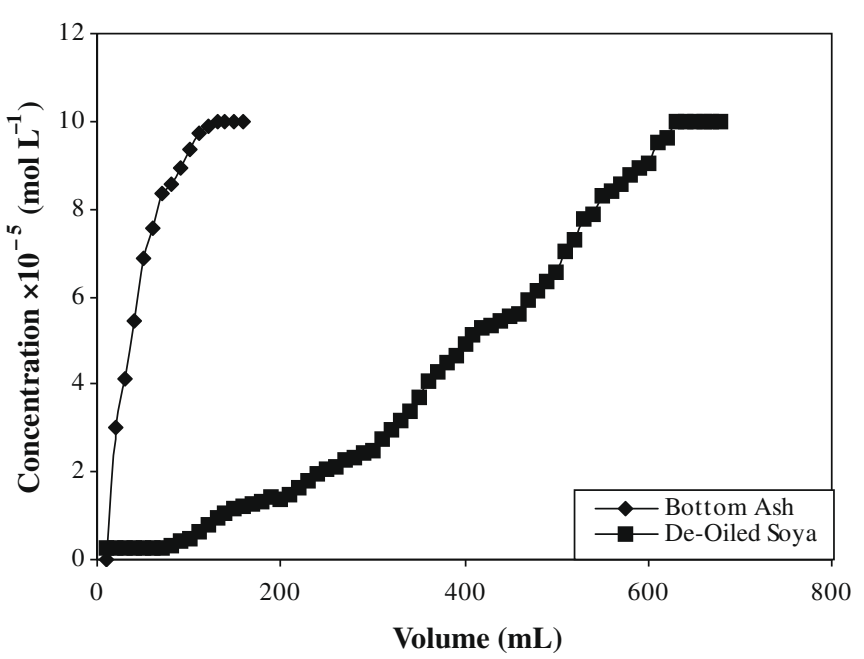

Fig. 13. Breakthrough curve for carmoisine $\mathrm{A}$-bottom ash and carmoisine $\mathrm{A}-$ deoiled soya columns.

$\ln \left(\frac{C_{t}}{C_{0}}-\frac{1}{1+m k}\right)=\left(\frac{1+m k}{m k} \beta_{\mathrm{L}} S_{\mathrm{S}}\right) t+\left(\frac{m k}{1+m k}\right)$,

where $C_{t}$ is the concentration of adsorbate $\left(\mathrm{mol} \mathrm{L}^{-1}\right)$ after time $t, C_{\mathrm{o}}$ is initial concentration of the adsorbate $\left(\mathrm{mol} \mathrm{L}^{-1}\right), k\left(\mathrm{~L} \mathrm{~g}^{-1}\right)$ is the constant $\left(Q_{0} \times b\right), m\left(\mathrm{~g} \mathrm{~L}^{-1}\right)$ and $S_{\mathrm{s}}\left(\mathrm{cm}^{-1}\right)$ are the mass and outer surface area of the adsorbent particles per unit volume, respectively, and $\beta_{\mathrm{L}}\left(\mathrm{cm} \mathrm{s}^{-1}\right)$ is the mass transfer coefficient

$S_{\mathrm{S}}=\frac{6 m}{\left(1-\varepsilon_{\mathrm{P}}\right) d_{\mathrm{p}} \rho_{\mathrm{P}}}$

where $d_{\mathrm{p}}$ is particle diameter $(\mathrm{cm}), \rho_{\mathrm{p}}$ is density of adsorbent $\left(\mathrm{g} \mathrm{cm}^{-3}\right)$, and $\varepsilon_{\mathrm{p}}$ is the porosity of the adsorbent particle.

The $\ln \left(\frac{c_{t}}{C_{0}}-\frac{1}{1+m k}\right)$ versus time plots for the bottom ash and deoiled soya provide the value of mass transfer coefficient for each system by the slope of straight lines obtained in each case. At $323 \mathrm{~K}$ values of mass transfer coefficient $\left(\beta_{\mathrm{L}}\right)$ are found to be $3.867 \times 10^{-8}$ and $3.063 \times 10^{-8} \mathrm{~cm} \mathrm{~s}^{-1}$ for the bottom ash and deoiled soya, respectively. These clearly signify the rapid mass transfer rate of the dye molecules on both adsorbents from bulk solution to solid phase and considerable affinity between the adsorbate and the adsorbent.

\subsection{Fixed-bed adsorption studies}

Practically, the fixed-bed adsorption process has been found to be more advantageous over the batch technique for the removal of toxic dye from industrial wastewaters. Bulk removal of the adsorbate by column studies proves to be more beneficial as the exhaustion capacity of column is usually relatively higher than the batch capacity [49]. This is due to formation of a continuous larger concentration gradient at the interface zone as the influent dye solution passes through the column. Thus for both adsorbents, fixed-bed column studies were carried out by employing well-established methods [50]. Through the prepared columns $10 \times 10^{-5} \mathrm{~mol} \mathrm{~L}^{-1}$ dye solution was passed at the rate of $0.5 \mathrm{~mL} \mathrm{~min}^{-1}$. Breakthrough curves of eluted volume versus concentration of the eluted dye for both systems are plotted and are portrayed in Fig. 13. It is found that out of $8.04 \mathrm{mg}$ of the

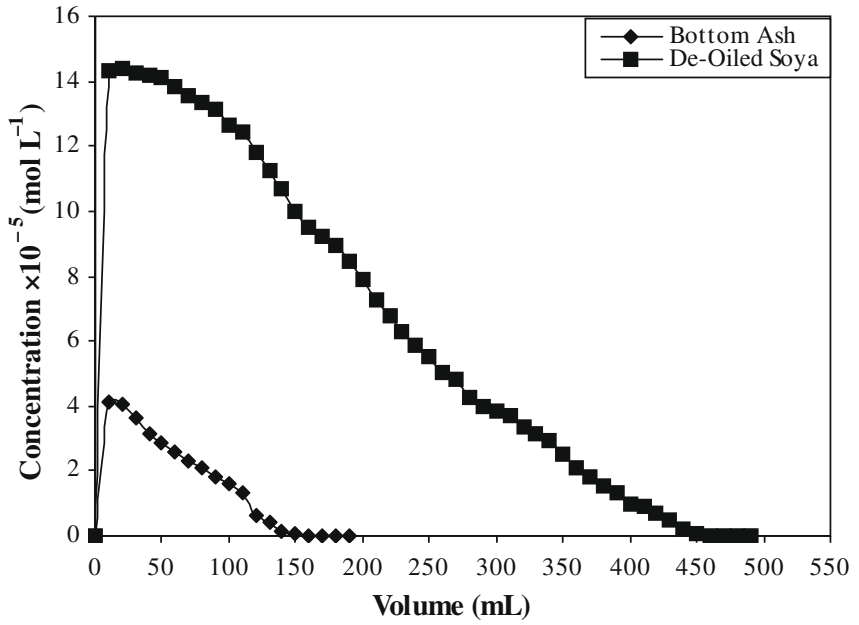

Fig. 14. Regeneration of carmoisine A from bottom ash and deoiled soya columns.

dye taken in the solution, $1.92 \mathrm{mg}$ is adsorbed over $0.2 \mathrm{~g}$ of bottom ash and for deoiled soya $(0.25 \mathrm{~g}) 19.53 \mathrm{mg}$ of the dye was adsorbed out of $34.16 \mathrm{mg}$ of the dye. The length of the primary adsorption zone $(\delta)$, total time involved for the establishment of primary adsorption zone $\left(t_{\mathrm{x}}\right)$, time for the primary adsorption zone to move down its length $\left(t_{\delta}\right)$, time for initial formation of primary adsorption zone $\left(t_{f}\right)$, mass rate flow of the adsorbent $\left(F_{\mathrm{m}}\right)$, and fractional capacity of the column $(f)$ were calculated from the breakthrough curves obtained in both cases by using following relations:

$t_{\mathrm{x}}=\frac{V_{\mathrm{x}}}{F_{\mathrm{m}}}$,

$t_{\delta}=\frac{V_{\mathrm{x}}-V_{\mathrm{b}}}{F_{\mathrm{m}}}$,

$\frac{\delta}{D}=\frac{t_{\delta}}{t_{\mathrm{x}}-t_{f}}=\frac{t_{\delta}}{t_{\mathrm{x}}+t_{\delta}(f-1)}=\frac{\left(V_{\mathrm{x}}-V_{\mathrm{b}}\right)}{V_{\mathrm{b}}+f\left(V_{\mathrm{x}}-V_{\mathrm{b}}\right)}$,

$f=1-\frac{t_{f}}{t_{\delta}}=\frac{M_{\mathrm{s}}}{\left(V_{\mathrm{x}}-V_{\mathrm{b}}\right) C_{\mathrm{o}}}$,

percentage saturation $=\frac{D+\delta(f-1)}{D} \times 100$.

The calculated values of these parameters are presented in Table 8. The data indicate that the values of $t_{\mathrm{x}}$ and $t_{\delta}$ for the carmoisine A-bottom ash adsorption are less than those for the carmoisine A-deoiled soya system. The data obtained also reveal that the time taken for the initial formation of primary adsorption zone $\left(t_{f}\right)$ is $40 \mathrm{~min}$ for bottom ash and $200 \mathrm{~min}$ for deoiled soya. For both systems the fractional capacity $f$, at breakpoint, was calculated around 0.99 , while percentage saturation was found to be $99.08 \%$ for the bottom ash column and $99.00 \%$ for the deoiled soya column.

\subsection{Desorption studies}

In order to recover the dye, $\mathrm{NaOH}$ solution ( $\mathrm{pH}$ 13) was allowed to percolate through the exhausted column under specified conditions of flow rate, column bed, etc. A figural depiction of collected volume of the eluent versus recovered amount of the dye is given in Fig. 14. Totals of 190 and $490 \mathrm{~mL}$ of dilute $\mathrm{NaOH}$ solution were

Table 8

Calculations for fixed-bed adsorbers-bottom ash and deoiled soya.

\begin{tabular}{|c|c|c|c|c|c|c|c|c|}
\hline Adsorbent & $C_{\mathrm{o}}\left(\mathrm{mol} \mathrm{L}^{-1}\right)$ & $C_{\mathrm{x}}\left(\mathrm{mol} \mathrm{L}^{-1}\right)$ & $C_{\mathrm{b}}\left(\mathrm{mol} \mathrm{L}^{-1}\right)$ & $F_{\mathrm{m}}\left(\mathrm{mg} \mathrm{cm}^{-2}\right)$ & $t_{\mathrm{x}}(\min )$ & $t_{\delta}(\min )$ & $t_{f}(\min )$ & Percentage saturation \\
\hline Bottom ash & $10 \times 10^{-5}$ & $10 \times 10^{-5}$ & $3 \times 10^{-5}$ & 0.032 & 4375 & 3750 & 40 & $99.08 \%$ \\
\hline Deoiled soya & $10 \times 10^{-5}$ & $10 \times 10^{-5}$ & $4.5 \times 10^{-6}$ & 0.032 & 20,311 & 17,186 & 200 & $99.00 \%$ \\
\hline
\end{tabular}


found to be sufficient for desorption of carmoisine A-bottom ash and carmoisine A-deoiled soya systems, respectively.

The collection of $50 \%$ of the desorbed dye was achieved by first $60 \mathrm{~mL}$ of the eluent for the bottom ash column and $180 \mathrm{~mL}$ was sufficient to recover the remaining amount of the dye. The total percentage recovery of the dye was almost $81 \%$. Similarly, during the regeneration of the deoiled soya column, $50 \%$ of the dye could be desorbed by the first $150 \mathrm{~mL}$ of the eluent and the remaining dye was obtained by eluting 34 more aliquots of $10 \mathrm{~mL}$ each, which made about $82 \%$ recovery of the dye. Both columns were then washed with hot water at a flow rate of $0.5 \mathrm{~mL} \mathrm{~min}^{-1}$.

\section{Summary}

This study investigated the adsorption process for carmoisine A-bottom ash and carmoisine A-deoiled soya under prescribed conditions of $\mathrm{pH}$, sieve size, concentration, temperature, etc. and establishes that both bottom ash and deoiled soya can be used as potential adsorbents for removal of carmoisine A from waste waters. Excellent adsorption abilities of both adsorbents could be very well predicted using Langmuir and Freundlich models. The monolayer adsorption capacity, at $323 \mathrm{~K}$, was found to be $1.78 \times 10^{-5}$ and $5.62 \times 10^{-5} \mathrm{~mol} \mathrm{~g}^{-1}$ for bottom ash and deoiled soya systems, respectively. The uptake capacity of both adsorption systems was found to increase with increase in temperature and the calculated values for thermodynamic parameters also specify the ongoing process as feasible and endothermic with increased randomness. The kinetic analysis led us to conclude that particle diffusion is operative in the adsorption process for both adsorbent systems. The percentage saturation is found to be $99.08 \%$ for bottom ash and $99.00 \%$ for deoiled soya. The dye can be recovered from these columns using $\mathrm{NaOH}$ solution as an eluent. The percentage recovery of the columns is found to be around $81 \%$ in each case. Thus, a conclusion can be drawn that both bottom ash and deoiled soya can act as selective adsorbers for removal and recovery of the hazardous dye carmoisine A from wastewaters.

\section{Acknowledgements}

One of the authors (Arti Malviya) is thankful to MANIT, Bhopal, for providing a fellowship under the Technical Education Quality Improvement Program (TEQIP).

\section{References}

[1] P. Banerjee, S.D. Gupta, S. De, J. Hazard. Mater. 140 (2007) 95-103.

[2] L.W. Lackey, R.O. Mines Jr., P.T. McCreanor, J. Hazard. Mater. 138(2006)357-362.

[3] M. Muruganandham, N. Sobana, M. Swaminathan, J. Hazard. Mater. 137 (2006) 1371-1376.

[4] L. Fan, Y. Zhou, W. Yang, G. Chen, F. Yang, J. Hazard. Mater. 137 (2006) 1182-1188.
5] M. Zhu, Y. Li, M. Xie, H. Xin, J. Hazard. Mater. 120 (2005) 163-171.

[6] F.A. Batzias, D.K. Sidiras, J. Hazard. Mater. 141 (2007) 668-679.

[7] B. Noroozi, G.A. Sorial, H. Bahrami, M. Arami, J. Hazard. Mater. 139 (2007) 167174.

[8] Y. Onal, J. Hazard. Mater. 137 (2006) 1719-1728.

[9] S. Wang, Z.H. Zhu, J. Hazard. Mater. 136 (2006) 946-952.

[10] M.M. Ramos-Tejada, A. Ontiveros-Ortega, E. Gimenez-Martin, M. EspinosaJimenez, A. Molina Diaz, J. Colloid Interface Sci. 297 (2006) 317-321.

[11] F. Akbal, J. Colloid Interface Sci. 286 (2005) 455-458.

[12] K. Kadirvelu, M. Kavipriya, C. Karthika, M. Radhika, N. Vennilamani, S. Pattabhi, Biores. Technol. 87 (2003) 129-132.

[13] S. Wang, Y. Boyjoo, A. Choueib, Z.H. Zhu, Water Res. 39 (2005) 129-138.

[14] S. Wang, Z.H. Zhu, J. Hazard. Mater. 126 (2005) 91-95.

[15] S. Wang, M. Soudi, L. Li, Z.H. Zhu, J. Hazard. Mater. 133 (2006) 243-251.

[16] L. Li, S. Wang, Z.H. Zhu, J. Colloid Interface Sci. 300 (2006) 52-59.

[17] S. Wang, H.W. Wu, J. Hazard. Mater. 136 (2006) 482-501.

[18] A. Mittal, J. Mittal, L. Kurup, J. Hazard. Mater. 136 (3) (2006) 567-578.

[19] V.K. Gupta, A. Mittal, V. Gajbe, J. Mittal, Ind. Eng. Chem. Res. 45 (2006) 14461453.

[20] A. Mittal, V. Gajbe, J. Mittal, J. Hazard. Mater. 150 (2008) 364-375.

[21] V.K. Gupta, A. Mittal, V. Gajbe, J. Mittal, J. Colloid Interface Sci. 319 (2008) 3039.

[22] A. Mittal, V.K. Gupta, A. Malviya, J. Mittal, J. Hazard. Mater. 151 (2008) 821832 .

[23] T.E. Tuormaa, J. Orthomol. Med. 9 (1994) 225-243.

[24] S.V. Mohan, N.C. Rao, J. Karthikeyan, J. Hazard. Mater. 90 (2002) 189-204.

[25] M.M. Biswas, K.E. Taylor, J.K. Bewtra, N. Biswas, Water Environ. Res. 79 (2007) 351-356.

[26] I.F. Gaunt, M. Farmer, P. Grasso, S.D. Gangoli, Food Cosmet. Toxicol. 5 (1967) 179-185.

[27] M.Y. Osman, I.A. Sharaf, H.M.Y. Osman, Z.A. El-khouly, El Ahmed, Br. J. Biomed. Sci. 61 (2004) 128-132.

[28] P.G. Reiger, H.M. Meir, M. Gerle, U. Vogt, T. Groth, H.J. Knackmuss, J. Biotechnol. 94 (2002) 101-123.

[29] H. Aboel-Zahab, Z. El-khyat, G. Sidhom, R. Awadallah, W. Abdel-al, K. Mahdy, Boll. Chim. Farm. 136 (1997) 615-627.

[30] S.A. Marathe, H.R. Adhikari, M.S. Netrawali, P.M. Nair, Food Chem. Toxicol. 31 (1993) 739-744.

[31] N.L. Hecht, D.S. Duvall, Characterization and Utilization of Municipal and Utility Sludges and Ashes, vol. III, Utility Coal Ash, National Environmental Research Center, US Environmental Protection Agency, 1975.

[32] S.V. Rama Rao, A.K. Panda, M.V.L.N. Raju, G. Shyam Sunder, N.K. Praharaj, Anim. Feed Sci. Technol. 106 (2003) 199-208.

[33] H.J. Fornwalt, R.A. Hutchins, Chem. Eng. J. 73 (1966) 179-186.

[34] B.H. Hameed, A.T.M. Din, A.L. Ahmad, J. Hazard. Mater. 141 (2007) 819-825.

[35] A.A. Ahmad, B.H. Hameed, N. Aziz, J. Hazard. Mater. 141 (2007) 70-76.

[36] W.H. Cheung, Y.S. Szeto, G. McKay, Biores. Technol. 98 (2007) 2897-2904.

[37] T.W. Weber, R.K. Chakrabarti, J. Am. Inst. Chem. Eng. 20 (1974) 228-238.

[38] C. Lu, Y. Chung, K. Chang, J. Hazard. Mater. 138 (2006) 304-310.

[39] J. Wu, H. Yu, J. Hazard. Mater. 137 (2006) 498-508.

[40] D. Kavitha, C. Namasivayam, Dyes Pigments 74 (2007) 237-248.

[41] E. Malkov, J. Hazard. Mater. 137 (2006) 899-908.

[42] N. Unlu, M. Ersoz, Sep. Purif. Technol. 52 (2007) 461-469.

[43] Y.S. Ho, J.F. Porter, G. McKay, Water Air Soil Pollut. 141 (2002) 1-33.

[44] B.S. Inbaraj, J.T. Chien, G.H. Ho, J. Yang, B.H. Chen, Biochem. Eng. J. 31 (2006) 204-215.

[45] Y.S. Ho, Water Res. 40 (2006) 119-125.

[46] E. Boyd, A.W. Adamson, L.S. Meyers, J. Am. Chem. Soc. 69 (1947) 2836-2848.

[47] D. Reichenberg, J. Am. Chem. Soc. 75 (1953) 589-597.

[48] S.J.A. McKay, I.F. McConvey, M.S. Ottorburn, J. Colloid Interface Sci. 80 (1981) 323-329.

[49] G. Bayramoglu, G. Celik, M.Y. Arica, J. Hazard. Mater. 137 (2006) 1689-1697.

[50] S.A. Figueiredo, J.M. Loureiro, R.A. Boaventura, Water Res. 39 (2005) 41424152. 